\title{
Biosynthesis of endotubin: an apical early endosomal glycoprotein from developing rat intestinal epithelial cells
}

\author{
Katrina ALLEN, K. Erden GOKAY, Mitchell A. THOMAS, Becky A. SPEELMAN and Jean M. WILSON ${ }^{1}$ \\ Department of Cell Biology and Anatomy and Department of Pediatrics, Steele Memorial Children's Research Center, University of Arizona, Tucson, AZ 85724, U.S.A.
}

Endosomes are the site of sorting of internalized receptors and ligands in all cell types and, in polarized cells, the apical endosomal compartment is involved in the selective transepithelial transport of immunoglobulins and growth factors. The biochemical composition of this specialized compartment remains largely unresolved. We have characterized a glycoprotein, called endotubin, that is located in the apical endosomal tubules of developing rat intestinal epithelial cells. A monoclonal antibody against endotubin recognizes a broad band of 55-60 kDa, which upon isoelectric focusing can be resolved into two bands, and a faint band of $140 \mathrm{kDa}$. Metabolic labelling followed by immunoprecipitation indicates that endotubin is synthesized as a $140 \mathrm{kDa}$ precursor that is cleaved to the 55-60 kDa forms. High $\mathrm{pH}$ washing of endosomal membranes removes the $55-60 \mathrm{kDa}$ forms from the membrane, whereas the high-molecular-mass form remains membrane associated and appears to be an integral membrane protein. Immunoblotting with a polyclonal antibody against the putative cytoplasmic tail of the protein identifies a $140 \mathrm{kDa}$ band and a band of $74 \mathrm{kDa}$, presumably the cleavage product. Immunoprecipitation with antibodies against the 55-60 $\mathrm{kDa}$ form results in coprecipitation of a $74 \mathrm{kDa}$ protein, and immunoprecipitation with antibody against the $74 \mathrm{kDa}$ protein results in coprecipitation of the 55-60 kDa form. Epitope mapping of the monoclonal antibody binding site supports a proposed type I membrane protein orientation. We propose that endotubin is proteolytically processed into a heterodimer with the 55-60 $\mathrm{kDa}$ fragment remaining membrane-associated through a noncovalent association with the membrane-bound $74 \mathrm{kDa}$ portion of the molecule.

\section{INTRODUCTION}

After endocytosis from the plasma membrane, internalized receptors and ligands are delivered to endosomes [1]. In this organelle, receptors and ligands are sorted and targeted to diverse intracellular locations. Endosomes are structurally and functionally heterogeneous [2-6] and, in polarized epithelial cells, the endosomal compartment is separated into apical and basolateral endosomal compartments [7-9]. The apical endosomal compartment has been implicated in both apical-tobasolateral and basolateral-to-apical transepithelial transport of immunoglobulins and growth factors [10-14]. However, little is known about the molecular structure of these specialized membranes and the features that allow them to sort internalized macromolecules.

We previously generated a monoclonal antibody against a glycoprotein, called endotubin, that has been shown by immunoelectron microscopy to be located in the apical tubular endosomes of absorptive cells in developing rat ileum [15]. On Western blots, this antibody recognizes a broad band of 55-60 $\mathrm{kDa}$ and a minor high-molecular-mass band of $140 \mathrm{kDa}$. Cloning and sequencing of the cDNA have demonstrated that endotubin is encoded by a single large messenger RNA which predicts a polypeptide of approx. $134 \mathrm{kDa}$ molecular mass [16]. This suggests that endotubin is synthesized as a large precursor that is then processed to the lower-molecular-mass forms. Proteolytic processing of cell surface enzymes and receptors has been demonstrated in other cell types, and is a hallmark of some apical plasma membrane enzymes of the intestine [27]. However, no endosomal or lysosomal membrane proteins have been reported to undergo this type of processing. Because endotubin is unique in its localization to the apical endosomal compartment, we wished to study its biosynthesis and processing. Using immunoprecipitation and immunoblotting, we analysed the biosynthesis of endotubin, as well as the nature of the membrane association of this protein and its topology with respect to the membrane. Our results suggest that endotubin is a type I integral membrane glycoprotein that is synthesized as a high-molecular-mass precursor that is proteolytically cleaved to yield a 55-60 kDa polypeptide and a $74 \mathrm{kDa}$ polypeptide. The $55-60 \mathrm{kDa}$ form remains associated with the membrane, possibly as a heterodimer with the $74 \mathrm{kDa}$ portion of the molecule.

\section{EXPERIMENTAL}

\section{Materials}

$\left[{ }^{35} \mathrm{~S}\right]$ Trans-label was obtained from ICN Pharmaceuticals (Costa Mesa, CA). Acrylamide, sodium dodecyl sulphate, Tris $/ \mathrm{HCl}$, and nitrocellulose were obtained from Bio-Rad Laboratories (Richmond, CA). The pMal-c vector and anti-maltose binding protein antibody were obtained from New England Biolabs (Beverley, MA). The nested deletion kit and Protein GSepharose were obtained from Pharmacia Biotech (Piscataway, NJ). Glycosidases and restriction enzymes were obtained from Boehringer Mannheim Biochemicals (Indianapolis, IN). Western Blue alkaline phosphatase substrate was obtained from Promega (Madison, WI) and chemiluminescence reagents were obtained from Amersham Life Science, Inc. (Cleveland, OH). All other reagents were obtained from Sigma Chemical Company (St. Louis, MO).

\section{Polyclonal anti-tail antibody production}

Rabbit polyclonal antibodies against the cytoplasmic tail of endotubin were generated by Research Genetics (Huntsville, AL). Animals were injected with the synthetic peptide S-T-DA-A-A-S-G-F-D-N-I-L-F-N-A-D (amino acid single-letter code) 
conjugated to multiple-antigen peptide resin. This peptide sequence corresponds to amino acids 1167-1183 near the carboxy terminus of the deduced amino acid sequence of endotubin [16]. Serum was diluted 1:100 for immunoblotting.

\section{Metabolic labelling and immunoprecipitation with the monoclonal antibody against endotubin}

All animal protocols were approved by the Institutional Animal Care and Use Committee. Explants of neonatal rat ileum were incubated for $15 \mathrm{~min}$ in methionine free DMEM and then transferred to medium containing $1 \mathrm{mCi} / \mathrm{ml}\left[{ }^{35} \mathrm{~S}\right]$ Trans-label and $20 \mu \mathrm{M}$ unlabelled methionine for $15 \mathrm{~min}$ at $37^{\circ} \mathrm{C}$. After labelling, explants were either solubilized or chased in complete medium for $180 \mathrm{~min}$ at $37^{\circ} \mathrm{C}$. Solubilization was performed in buffer

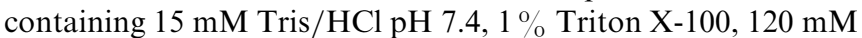
$\mathrm{NaCl}, 25 \mathrm{mM} \mathrm{KCl}, 1 \mu \mathrm{g} / \mathrm{ml}$ aprotinin and leupeptin, $0.25 \mathrm{mM}$ PMSF and $1.7 \mu \mathrm{g} / \mathrm{ml}$ DNAase. After solubilization, samples were spun briefly to remove debris and immunoprecipitated with anti-endotubin-Sepharose. The immunoprecipitates were separated by SDS/PAGE [18] and exposed to Kodak XAR film at $-80{ }^{\circ} \mathrm{C}$ with intensifying screens.

For labelling of cells in culture, $2 \mathrm{~cm}$ round dishes were plated with NRK cells that had been stably transfected with the endotubin cDNA [19]. The cells were incubated with $10 \mathrm{mM}$ sodium butyrate overnight before metabolic labelling. Cells were pulsed for $10 \mathrm{~min}$ at $37^{\circ} \mathrm{C}$ as described above and either solubilized or chased for $60 \mathrm{~min}$ at $37^{\circ} \mathrm{C}$ followed by a $100000 \mathrm{~g}$ spin for $1 \mathrm{~h}$ and immunoprecipitation with anti-endotubin and Protein G-Sepharose. Immunoprecipitates were separated by SDS/PAGE, transferred to nitrocellulose, and quantitated using a Packard Instant Imager.

\section{Immunoprecipitation with the anti-tail polyclonal antibody}

Epithelial cells were isolated from neonatal rat ileum as described [15]. Cells were solubilized as described above. After solubilization, samples were spun at $100000 \boldsymbol{g}$ for $1 \mathrm{~h}$. Anti-tail polyclonal antibody serum was added to a dilution of $1: 125$ and the homogenate was incubated for $2 \mathrm{~h}$ at $4{ }^{\circ} \mathrm{C}$ with constant agitation. Protein G-Sepharose was washed with solubilization buffer and added to the immunoprecipitation system for $30 \mathrm{~min}$ at $4{ }^{\circ} \mathrm{C}$. The beads were washed three times in solubilization buffer followed by one wash with TBS. Proteins were eluted by boiling in sample buffer and separated by SDS/PAGE followed by transfer to nitrocellulose. To detect the $55-60 \mathrm{kDa}$ form of endotubin, blots were then incubated with the monoclonal antibody against endotubin as described below and visualized using chemiluminescence.

\section{Immunoblotting}

After separation by SDS/PAGE, proteins were transferred to nitrocellulose using a semi-dry transfer apparatus for $60 \mathrm{~min}$ at $12 \mathrm{~V}$. Blots were blocked using $5 \%$ milk in Tris-buffered saline containing $0.1 \%$ Tween 20 and then incubated with the monoclonal antibody diluted 1:1 with blocking buffer followed by anti-mouse antibody conjugated to alkaline phosphatase or horseradish peroxidase. In the case of polyclonal antibodies, antibodies were diluted 1:100 (anti-tail antibody) or 1:5000 (anti-maltose binding protein antibody) in blocking buffer followed by anti-rabbit antibody conjugated to alkaline phosphatase. Blots were developed using Western Blue alkaline phosphatase substrate.

\section{Carbonate washing of endosomal membranes}

Endosomal membranes (20 $\mu \mathrm{g}$ protein) isolated as described [15] were diluted in $0.25 \mathrm{M}$ sucrose, mixed with $25 \mathrm{mM} \mathrm{Na}_{2} \mathrm{CO}_{3}, \mathrm{pH}$ 11 , and placed in ice for $1 \mathrm{~h}$. The mixture was centrifuged for $1 \mathrm{~h}$ at $100000 \mathrm{~g}$ in a Beckman Airfuge. The pellet and supernatant were separated by $7.5 \%$ SDS/PAGE, transferred to nitrocellulose, and immunoblotted with the monoclonal antibody.

\section{Epitope mapping of monoclonal antibody binding site}

To determine the region of the protein that contained the epitope recognized by the monoclonal antibody used throughout these studies a $991 \mathrm{bp}$ fragment derived from the $5^{\prime}$ end of the coding region (bp 269-1260, amino acids 50-379) [16] was subcloned into the pMal-c vector for production of a maltose binding protein-endotubin fusion protein. A combination of restriction enzyme deletion and nested deletions followed by SDS/PAGE and immunoblotting with the monoclonal antibody was used to identify the antigenic epitope. Duplicate blots were incubated with antibodies against the maltose binding protein.

\section{Affinity purification of endotubin from neonatal rat ileum}

Epithelial cells were isolated as described previously [15]. For each antigen isolation, ten 15-day-old neonatal rats were used. Endotubin was isolated as described using an anti-endotubin monoclonal antibody column [16]. Fractions containing endotubin were concentrated by trichloroacetic acid precipitation, and immunoblotting confirmed that the purified antigen crossreacted with the monoclonal antibody.

\section{Glycosidase digestion of purified endotubin}

To determine the extent of $\mathrm{N}$-linked glycosylation, purified endotubin was digested to completion with $\mathrm{N}$-glycosidase $\mathrm{F}$. $100 \mathrm{ng}$ of endotubin was denatured and digested for $20 \mathrm{~h}$ at $37{ }^{\circ} \mathrm{C}$ with 0.4 unit of $\mathrm{N}$-glycosidase F. Digests were separated by SDS $/ 10 \%$-PAGE, transferred to nitrocellulose, and immunoblotted with the monoclonal antibody against endotubin.

To determine the contribution of high mannose and complex $N$-linked carbohydrate chains, purified endotubin was digested with endo- $\beta$-acetylglucosaminidase $\mathrm{H}$ (Endo $\mathrm{H}$ ) and endo- $\beta$ acetylglucosaminidase $\mathrm{F}$ (Endo F). Digestions were performed according to manufacturer's directions. For Endo $\mathrm{H}$ digestion, $200 \mathrm{ng}$ of endotubin was denatured and digested with 5 munits of Endo $\mathrm{H}$ for $18 \mathrm{~h}$ at $37^{\circ} \mathrm{C}$. For Endo $\mathrm{F}$ digestion, $200 \mathrm{ng}$ of endotubin was denatured and digested with 0.25 unit of Endo F. For digestion with both Endo $\mathrm{H}$ and Endo $\mathrm{F}$, samples were first digested with Endo $\mathrm{H}$, reboiled and digested with Endo F. Controls were incubated without added enzyme. Trichloroacetic acid precipitation $(10 \% \mathrm{v} / \mathrm{v})$ was carried out in the presence in $100 \mu \mathrm{g}$ of transfer RNA, and samples were immunoblotted as described above.

\section{RESULTS}

\section{Western blotting of endotubin identifies three forms}

Western blotting of endosomal membranes from neonatal rat intestine using a previously described monoclonal antibody [15] labels three forms of endotubin. Two of the forms are present in 
A

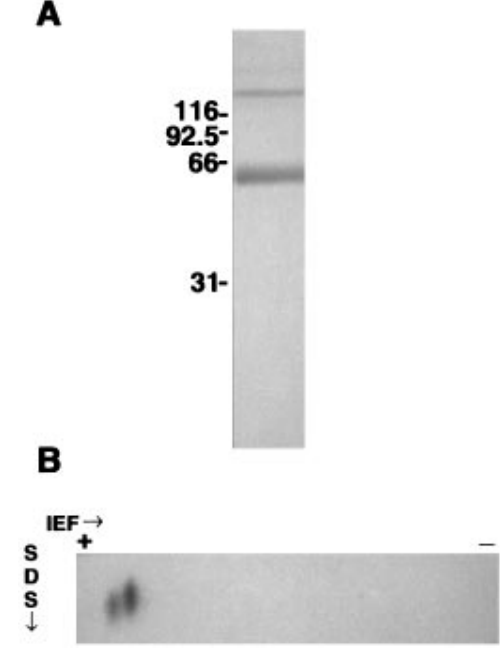

Figure 1 Immunoblot of neonatal rat intestinal cell membranes and isoelectric focusing of the $50-60 \mathrm{kDa}$ band

(A) Immunoblot of neonatal rat intestinal epithelial cell membranes using the monoclonal antibody against endotubin. There is a broad band of $55-60 \mathrm{kDa}$ and a minor band of 140 $\mathrm{kDa}$. (B) Isoelectric focusing of the 55-60 kDa band shows that the broad band is composed of two separate bands of slightly different isoelectric points.

a strongly reactive diffuse band of 55-60 kDa (Figure 1A). Upon isoelectric focusing, the diffuse band can be separated into two spots (Figure 1B). Under these conditions, the lower-molecularmass band is slightly more acidic. In addition to these lowermolecular-mass forms, there is a much fainter high-molecular mass band of 140000 (Figure 1A). This band does not appear to be due to non-reduced multimers of the low-molecular-mass band, as electrophoresis under non-reducing conditions does not decrease the amount of the $55-60 \mathrm{kDa}$ band and this band migrates more rapidly (data not shown).

\section{Metabolic labelling and immunoprecipitation of endotubin}

Southern and Northern blot analysis have suggested that there is a single gene and a single mRNA for this protein [16]. Therefore, it is unlikely that the different bands seen on Western blots are due to multiple genes or mRNAs for this protein. However, the cDNA encoding endotubin predicts a polypeptide of $133769 \mathrm{Da}$, significantly larger than the lower-molecular-mass form. Also, in vitro transcription and translation of the endotubin cDNA results in a single, high-molecular-mass band [16]. These observations suggested that endotubin is synthesized as a large precursor and post-translationally modified to yield the more abundant lower-molecular-mass bands. To determine if the 140 $\mathrm{kDa}$ band is a precursor of the lower-molecular-mass bands, explants of rat ileum were metabolically labelled and immunoprecipitated using the monoclonal antibody conjugated to Sepharose. After a 15 min pulse, a high-molecular-mass band is immunoprecipitated in addition to a faint broad band of molecular mass $55-60 \mathrm{kDa}$ (Figure 2A). After $180 \mathrm{~min}$ of chase, the high-molecular-mass band is much less evident and the $55-60 \mathrm{kDa}$ band more prominent. In addition, a band of approx. $74 \mathrm{kDa}$ is also present. The rapid appearance of the $55-60 \mathrm{kDa}$ band suggested that the proteolytic cleavage of endotubin occurred shortly after synthesis. To study this further, we utilized cells that had been transfected with the endotubin cDNA [19]. In these experiments the cells were pulsed for $10 \mathrm{~min}$ at $37^{\circ} \mathrm{C}$

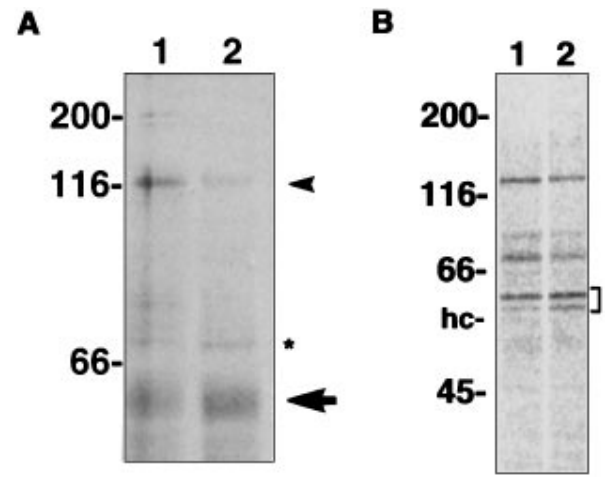

Figure 2 Metabolic labelling and immunoprecipitation of endotubin

(A). Immunoprecipitation of endotubin in neonatal rat intestine using the monoclonal antibody after a 15 min pulse (lane 1) results in a high molecular weight band (arrowhead) and a faint 55-60 kDa band (arrow). After a 180 min chase, the 55-60 kDa band is much more prominent, and the high molecular weight band is less evident (lane 2). A $74 \mathrm{kDa}$ band is also coprecipitated (asterisk). (B). Immunoprecipitation and quantitation of metabolically labelled endotubin from transfected NRK cells. The $140 \mathrm{kDa}, 74 \mathrm{kDa}$ and $55-60 \mathrm{kDa}$ bands are visualized after a $10 \mathrm{~min}$ pulse (lane 1). After $60 \mathrm{~min}$ of chase, the $140 \mathrm{kDa}$ band is decreased with a concomitant increase in the 55-60 kDa band (lane 2). Bracket indicates the area of quantitation of the 55-60 $\mathrm{kDa}$ band. hc, heavy chain of $\operatorname{lgG}$

followed immediately by solubilization or chased for $60 \mathrm{~min}$ at $37^{\circ} \mathrm{C}$ followed by solubilization and immunoprecipitation with the monoclonal antibody. Even after this short pulse, the 55$60 \mathrm{kDa}$ band was present (Figure 2B), suggesting that proteolytic processing occurred soon after synthesis. Quantitation of the $55-60 \mathrm{kDa}$ and $140 \mathrm{kDa}$ bands in the pulse and chase showed that the $140 \mathrm{kDa}$ band decreases from $1201 \pm 255$ counts to $645 \pm 112$ counts, whereas the $55-60 \mathrm{kDa}$ band increased from $1583 \pm 153$ to $2110 \pm 182$ counts $(n=3)$, suggesting a precursor/ product relationship. A surprising result was the fact that we did not see a change in the molecular mass of the 55-60 kDa band after the chase period, which would be expected for the conversion of glycosylated protein from a precursor to the mature form. However, this finding has been reported for high density lipoprotein receptor, which also contains a mixture of high mannose and complex $N$-linked carbohydrates [20, see below].

\section{Immunoblotting with anti-cytoplasmic tail antibody}

Analysis of the cDNA sequence has indicated that the 55-60 $\mathrm{kDa}$ fragment of endotubin is at the N-terminus of the protein and the single putative transmembrane domain at the C-terminus of the protein [16]. To assess further the relationship between the high-molecular-mass band and the 55-60 kDa forms, we used a polyclonal antibody generated against a synthetic peptide from the putative cytoplasmic tail of the molecule which is located at the extreme C-terminus of the protein. If endotubin is encoded as a high-molecular-mass precursor that is post-translationally cleaved, this antibody should identify the high-molecular-mass band as well as a lower-molecular-mass cleavage product, but not the 55-60 kDa form. When Western blots of neonatal rat ileum are incubated with this antibody, a band of molecular mass $140 \mathrm{kDa}$, corresponding in position to the band seen with the monoclonal antibody, is present (Figure 3). In addition, a band of molecular mass $74 \mathrm{kDa}$ is present, presumably representing the cleavage product. Incubation with pre-immune serum resulted in no bands on the immunoblot. 


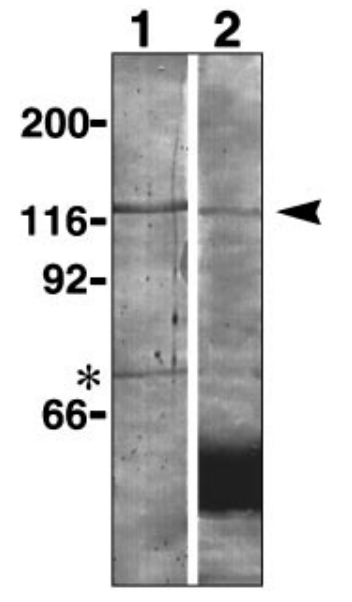

Figure 3 Immunoblot of neonatal rat ileum epithelial cells with polyclonal anti-tail antibody

Anti-tail antibody recognizes a band of $140 \mathrm{kDa}$ (arrowhead) and a band of $74 \mathrm{kDa}$ (asterisk) (lane 1). Incubation with the monoclonal antibody identifies the $140 \mathrm{kDa}$ band and the 55-60 kDa band (lane 2).
A

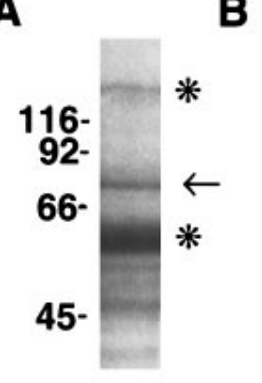

B

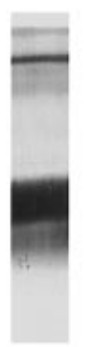

C

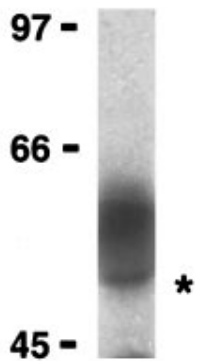

Figure 4 Co-immunoprecipitation with monoclonal and polyclonal antibodies

(A) Coomassie blue stained SDS/PAGE of affinity-purified endotubin using the monoclonal antibody. Bands at molecular mass $140 \mathrm{kDa}, 74 \mathrm{kDa}$ and $55-60 \mathrm{kDa}$ are present. Lowermolecular-mass bands presumably represent degradation products of the $55-60 \mathrm{kDa}$ band, since they are positive on the immunoblot shown in $(\mathbf{B})$. (B) Western immunoblot of affinitypurified material shown in $(\mathbf{A})$. The $140 \mathrm{kDa}$ and 55-60 kDa bands react with the monoclonal antibody. However, the $74 \mathrm{kDa}$ band does not. (C) Immunoprecipitation of neonatal rat gut with the polyclonal anti-tail antibody followed by immunoblotting with the monoclonal antibody. The $55-60 \mathrm{kDa}$ band is present on the immunoblot, indicating that it is co-precipitated with $74 \mathrm{kDa}$ protein. The asterisk marks the position of the heavy chain of the polyclonal antibody.

\section{Co-immunoprecipitation of the $74 \mathrm{kDa}$ and $55-60 \mathrm{kDa}$ forms}

To determine if the $74 \mathrm{kDa}$ and $55-60 \mathrm{kDa}$ forms of endotubin were remaining associated after cleavage of the $140 \mathrm{kDa}$ precursor, homogenates of ileal enterocytes were subjected to immunoprecipitation with the monoclonal antibody against the luminal domain or with the anti-cytoplasmic tail polyclonal antibody followed by SDS/PAGE (Figure 4). Immunoprecipitation with the monoclonal antibody followed by SDS/ PAGE and Coomassie Blue staining resulted in the identification of bands at $55-60 \mathrm{kDa}, 74 \mathrm{kDa}$ and $140 \mathrm{kDa}$. Immunoblotting with the monoclonal antibody against the $55-60 \mathrm{kDa}$ portion identified the 55-60 kDa band and the $140 \mathrm{kDa}$, but not the 74 $\mathrm{kDa}$ band. To test further if the $55-60 \mathrm{kDa}$ band remained associated with the $74 \mathrm{kDa}$ band, we performed the reverse

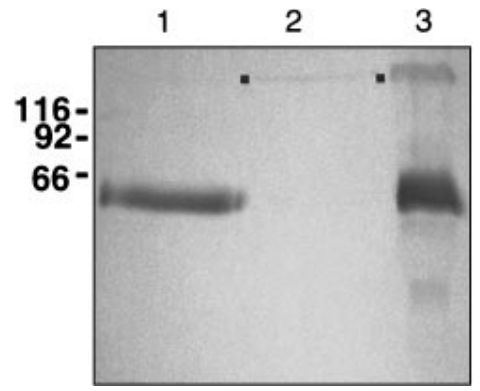

Figure 5 Monoclonal antibody immunoblot of membrane pellet and supernatant after carbonate washing of endosomal membranes

After high-pH washing, the $55-60 \mathrm{kDa}$ band is recovered in the supernatant (lane 1). The $140 \mathrm{kDa}$ band (bullets) remains in the membrane pellet (lane 2). Control (unwashed) membranes are in lane 3.

experiment and carried out the immunoprecipitation with the polyclonal anti-tail antibody followed by immunoblotting using the monoclonal antibody. After immunoprecipitation with the anti-tail antibody, immunoblotting with the monoclonal antibody identified the $55-60 \mathrm{kDa}$ form of endotubin. These coimmunoprecipitation results suggest that these two subunits remain associated after cleavage of the $140 \mathrm{kDa}$ precursor.

\section{Carbonate washing of endosomal membranes}

Previous studies on endotubin had shown that the majority of the $55-60 \mathrm{kDa}$ form of the glycoprotein partitioned with the detergent phase upon Triton X-114 extraction, suggesting that the protein was an integral membrane protein [15]. However, as mentioned above, sequence analysis suggested that the 55-60 $\mathrm{kDa}$ fragment is at the $\mathrm{N}$-terminus of the molecule and the single putative transmembrane domain at the $\mathrm{C}$-terminus of the protein [16]. Since the 55-60 kDa form co-precipitates with the putative membrane-anchored part of the molecule, it is possible that the behaviour of the $55-60 \mathrm{kDa}$ form during Triton X-114 phase partitioning is due to the non-covalent association of the lowermolecular-mass form with the membrane bound tail. To determine if the lower-molecular-mass form could be stripped from the membrane with high $\mathrm{pH}$, membranes were washed with $\mathrm{Na}_{2} \mathrm{CO}_{3}$, pH 11, centrifuged and immunoblotted. After high$\mathrm{pH}$ washing, the lower-molecular-mass form was found in the supernatant, indicating that it had been removed from the membrane (Figure 5). However, the high-molecular-mass form was still recovered in the membrane pellet. These results suggest that the $55-60 \mathrm{kDa}$ form is non-covalently linked to the membrane, most likely by association with the membrane-bound $74 \mathrm{kDa}$ portion of the precursor.

\section{Epitope mapping of the monoclonal antibody binding site}

Morphological studies have suggested that the epitope recognized by the monoclonal antibody is present on the luminal domain of the molecule [15]. To characterize further the topology of endotubin with respect to the membrane, the cDNA was used to map the position of this antigenic epitope. Expression of a maltose binding protein fusion protein containing amino acids $50-379$ resulted in a $72 \mathrm{kDa}$ fusion protein that contained the antigenic epitope (Figure 6A). Digestions removing as little as $359 \mathrm{bp}$ (120 amino acids) from the $3^{\prime}$ end of the fragment removed the antigenic epitope, indicating that the epitope was 
A.

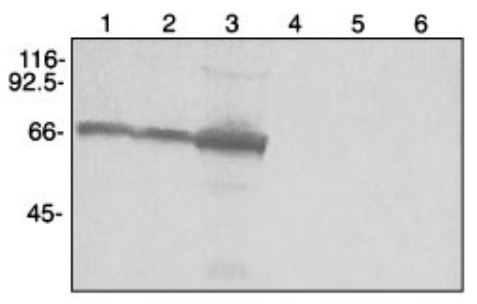

B.

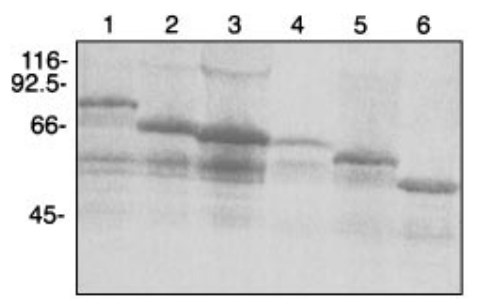

Figure 6 Epitope mapping of the monoclonal antibody binding site

(A) Immunoblot of deletions using anti-endotubin monoclonal antibody; (B) Immunoblot of deletions using anti-maltose binding protein antibody. Lane 1, maltose-binding proteinendotubin fusion protein, bp 269-1259, amino acids 50-379; lane 2, deletion of 138 bp, amino acids 50-333 remain; lane 3, deletion of 276 bp, amino acids 50-287 remain; lane 4, deletion of $359 \mathrm{bp}$, amino acids 50-260 remain; lane 5, deletion of $480 \mathrm{bp}$, amino acids 50-220 remain; lane 6 , deletion of $754 \mathrm{bp}$, amino acids 50-128 remain.

nearer the carboxyl end of the fragment. Exonuclease deletion from the $3^{\prime}$ end resulted in the deletion of $276 \mathrm{bp}$ (92 amino acids) with the conservation of the epitope. Immunoblotting of duplicate blots with antibodies against the maltose binding protein confirmed the estimated deletion sizes (Figure 6B). When the reading frame of the cDNA is taken into consideration, this analysis narrows the epitope to 28 amino acids at position 258-287 in the mature protein. These results, together with the location of the canonical $N$-linked glycosylation sites [16], further support the proposed Type I orientation of this protein and indicate that the antigenic epitope is on the luminal face of the membrane.

\section{Glycosidase digestion of purified 55-60 kDa and 140 kDa endotubin}

Proteins of the vacuolar system have been shown to have $N$ - and $O$-linked carbohydrate residues, and previous work using chemical deglycosylation has shown that endotubin was glycosylated [15]. In addition, there are six consensus signals for $N$-linked glycosylation in the cDNA encoding endotubin, four within the domain encoding the $55-60 \mathrm{kDa}$ form [16]. To characterize the types of glycosylation present on this molecule, we performed glycosidase digestion on purified endotubin. First, to determine the contribution of $N$-linked carbohydrates to the glycoprotein, endotubin was deglycosylated with $N$-glycanase. This glycanase cleaves all asparagine-bound $N$-linked glycans between asparagine and the carbohydrate chain [21]. After this treatment, the lower-molecular-mass band formed a doublet of 44 and $43 \mathrm{kDa}$, and the high-molecular-mass band shifted to approx. $130 \mathrm{kDa}$ (Figure 7A). Sequential digestion with $N$-glycanase, neuraminidase and $O$-glycanase resulted in no further shift in molecular mass (not shown), suggesting that there are no $O$-linked carbohydrates on this protein. These results indicate that the
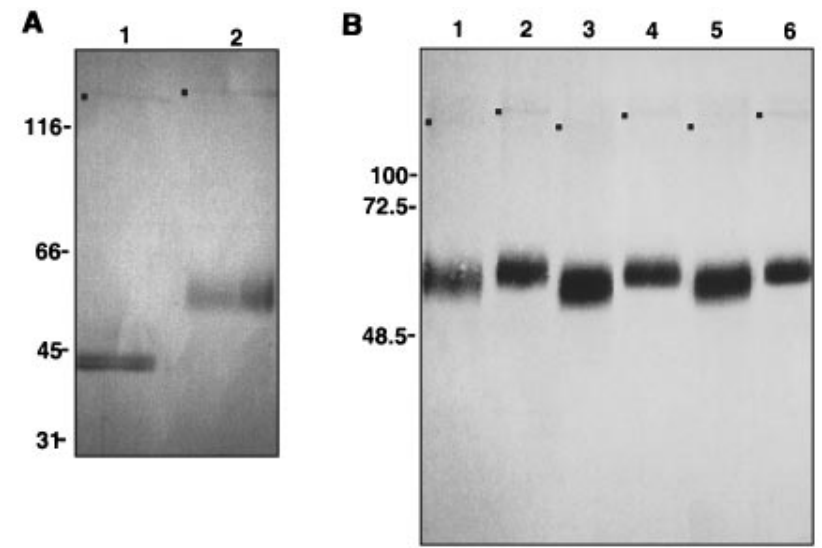

Figure 7 Monoclonal antibody immunoblot of purified endotubin and endoglycosidase $\mathrm{H}$ and $\mathrm{F}$ digestion of purified endotubin

(A) Monoclonal antibody immunoblot of purified endotubin after $\mathrm{N}$-glycanase treatment. Lane 1 , removal of $N$-linked chains results in a doublet of $43 \mathrm{kDa}$ and $44 \mathrm{kDa}$, and the high-molecularmass band (bullets) shifts to $130 \mathrm{kDa}$. Lane 2, control incubated without $\mathrm{N}$-glycanase. (B) Endoglycosidase $\mathrm{H}$ and Endoglycosidase $\mathrm{F}$ digestion of purified endotubin. Endotubin was incubated with (lane 1) or without (lane 2) Endo $\mathrm{H}$ and Endo $\mathrm{F}$, with (lane 3) or without (lane 4) Endo $\mathrm{H}$, and with (lane 5) or without (lane 6) Endo F. The lower bands shift 1.5-2 kDa. The $10 \mathrm{kDa}$ shift of higher-molecular-mass band is difficult to visualize, and the location of the bands is bulleted.

differences in molecular mass of the lower-molecular-mass forms are not due to differential glycosylation. Interestingly, doublet forms of both plasma membrane proteins and lysosomal membrane proteins have been previously reported $[22,23]$.

To further characterize the $N$-linked carbohydrates of endotubin, purified protein was subjected to digestion with endoglycosidases $\mathrm{H}$ and $\mathrm{F}$. Endoglycosidase $\mathrm{H}$ cleaves high mannose oligosaccharides, whereas endoglycosidase $F$ cleaves highmannose and complex carbohydrates [24]. However, endoglycosidase $\mathrm{F}$ does not cleave tri- and tetra-antennary complex $N$-carbohydrates [21]. Digestion with either glycosidase resulted in a shift of the entire diffuse band of 1.5-2 kDa (Figure 7B). In addition, samples incubated with Endoglycosidase $\mathrm{H}$ and $\mathrm{F}$ together did not shift more than either enzyme alone (Figure 7B). In contrast, the high-molecular-mass band shifted approx. $10 \mathrm{kDa}$, to $130 \mathrm{kDa}$. The greater mobility shift of this band is to be expected if it is, in fact, a precursor form, containing only high mannose $N$-glycans. Therefore, if we estimate that each high mannose oligosaccharide has a mass of $2-4 \mathrm{kDa}$, these results indicate that the lower-molecular-mass bands contain a single high mannose oligosaccharide chain and 2-3 other $N$-linked carbohydrates that contain complex tri- or tetra-antennary chains.

\section{Structural motifs present in endotubin}

The function of endotubin remains unknown. However, because of the similarities in the biosynthesis of some brush border enzymes and endotubin, we compared the sequence of endotubin to itself and to the sequences that scored highest from Blast computer analysis. As shown in Figure 8, endotubin has a weak internal repeat structure that occurs at approx. 300 amino acid intervals (Figure 8A). Blast analysis had shown that the MAM (meprin/A5/protein tyrosine phosphatase $\mu$ ) domain has the strongest relationship to endotubin, followed by the serine protease enteropeptidase. Enteropeptidase is a mosaic enzyme that contains domains that are related to the low-density 


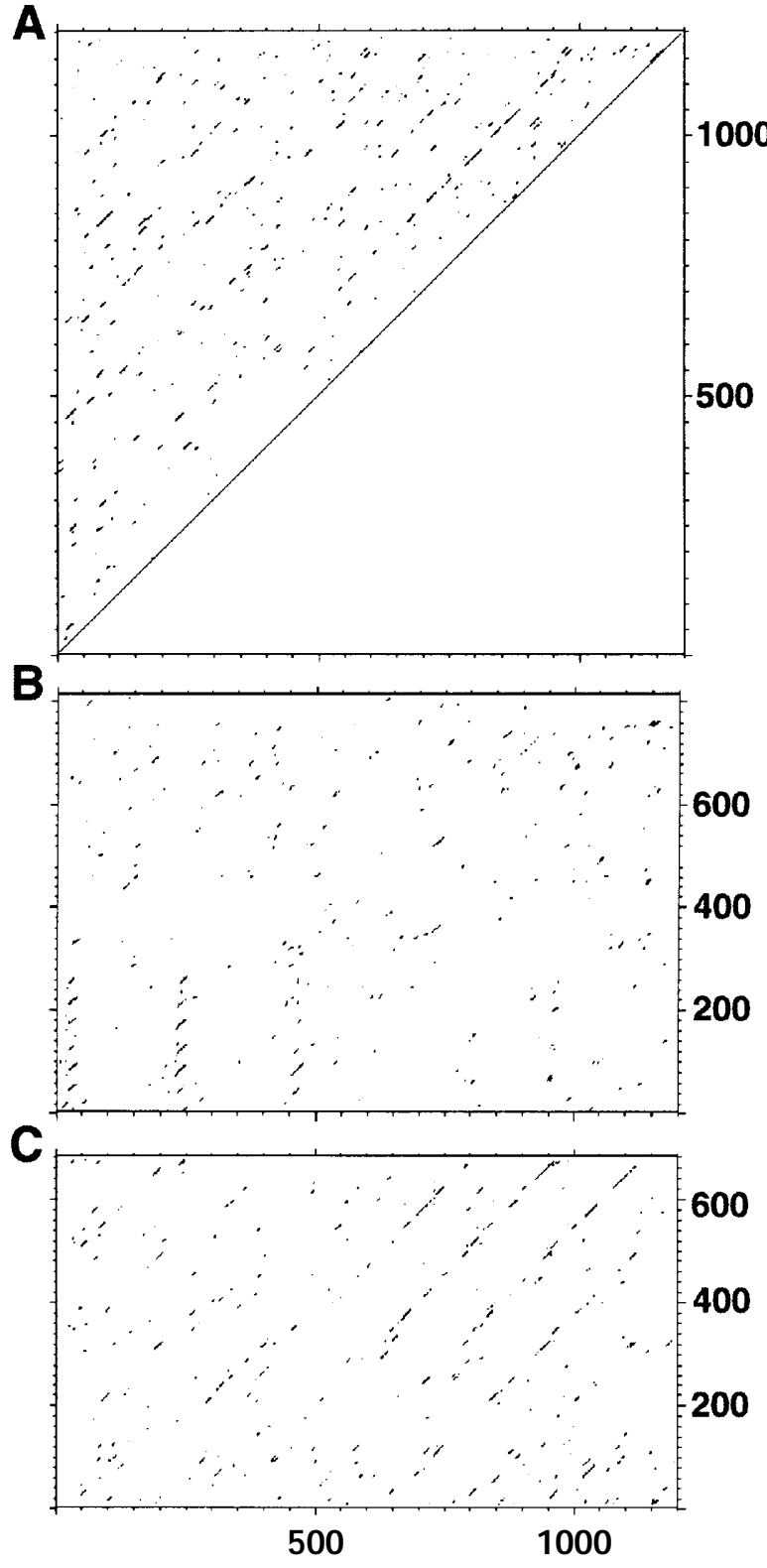

Figure 8 Dot matrix analysis of endotubin (L37380) to itself (A), the LDL receptor (B) (P35951) and the MAM peptide (C) (U37376)

Window size was 15 amino acids with a match of five amino acids. (A) Internal repeats are present in endotubin at intervals of approx. 300 amino acids. (B) Similarity to LDL receptor is present in the amino terminal part of the molecule. (C) Similarity to the MAM peptide is seen in the carboxy terminus of the protein.

lipoprotein receptor and meprin A [24], and previous analysis [16] had shown that endotubin is related to the LDL family of proteins. Dot matrix analysis of the relationship between endotubin and the LDL receptor showed that LDL-receptor related repeats are present in the $\mathrm{N}$-terminal half of the protein (Figure 8B) and the similarities with the MAM domain are found in the carboxy half of the protein (Figure 8C). However, although the domain structure of endotubin is similar to that found in enteropeptidase, neither of the active sites present in enteropeptidase or meprin A is found in endotubin, so it is unlikely that endotubin is functioning as a serine protease or metalloendopeptidase.

\section{DISCUSSION}

In this report, we have studied the biosynthesis and processing of endotubin, a glycoprotein that is present in the apical early endosomes of developing rat intestinal epithelial cells [15,26]. The suggested topology of endotubin and the location of structural domains are illustrated in Figure 9. Like several of the enzymes of the apical plasma membrane of intestinal epithelial cells [17], it appears that this protein is synthesized as a large membrane bound precursor that is cleaved, and the cleaved luminal domain remains non-covalently associated with the membrane. Co-immunoprecipitation of $74 \mathrm{kDa}$ and $55-60 \mathrm{kDa}$ forms with antibodies directed at two different parts of the molecule supports the model that the 55-60 kDa form and the $74 \mathrm{kDa}$ form remain associated as a heterodimer.

The intracellular sites of proteolytic cleavage of intestinal microvillar enzymes vary. The brush-border enzyme sucraseisomaltase is thought to be processed by pancreatic enzymes after insertion into the plasma membrane [27]. This is supported by results that showed that only the uncleaved precursor form of sucrase-isomaltase is present in fetal intestinal transplants that are not accessible to pancreatic proteases [28,29]. Also, in fetal gut which has been induced to express sucrase-isomaltase, the precursor form is the only form detected [30]. In the case of lactase-phlorizin, cleavage is thought to occur intracellularly [31] and cleavage has been suggested to be a late Golgi event, although cleavage at the cell surface may also occur [32]. Also in contrast to sucrose isomaltase, lactase-phlorizin is present in the processed form at 21 days gestation, in rats [30]. In the case of meprin A, at least some processing of the $\alpha$ subunit of this protease occurs in the endoplasmic reticulum [33,34]. The cleaved form of endotubin is detected in fetal rat intestine at 20 days of gestation [26], suggesting that intracellular proteases are im-

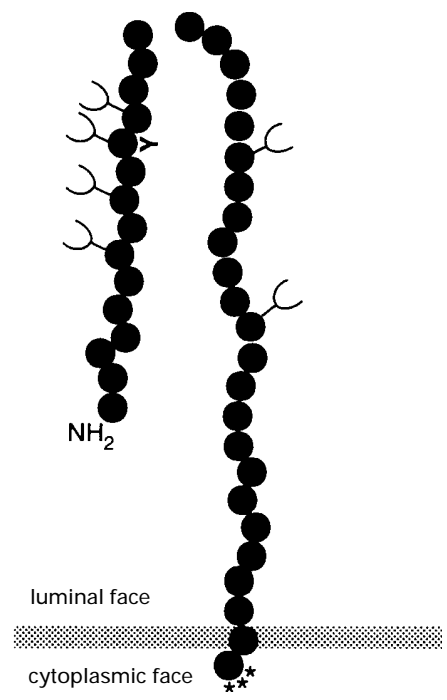

\section{Figure 9 Suggested topology of mature endotubin}

Each ball represents approx. 30 amino acids. The amino terminus of the protein is on the luminal side of the membrane, and the portion of the molecule containing the monoclonal antibody epitope $(Y)$ remains associated with the membrane through interaction with membrane anchored precursor. The anti-tail polyclonal antibody was generated against a peptide corresponding in location to the asterisks. Possible sites of $\mathrm{N}$-linked glycosylation are indicated by branches. 
portant in its processing. The fact that the cleaved form of endotubin is detected in cells that have been metabolically labelled for only $10 \mathrm{~min}$ further supports the hypothesis that intracellular proteases are important for this processing event, most likely in the endoplasmic reticulum. In addition to meprin A processing, the endoplasmic reticulum has been suggested to be the site of cleavage of several proteins $[35,36]$. However, the enzymes responsible for proteolytic processing events in the endoplasmic reticulum remain largely uncharacterized. Another possible mechanism for processing is autocatalytic cleavage, which has been reported for aspartylglucosaminidase and the $20 \mathrm{~S}$ proteasome $[37,38]$. This mechanism seems unlikely to be important in endotubin processing, since expression of the cDNA encoding endotubin in several cell lines results in only the 140 $\mathrm{kDa}$ form of the molecule (K. Allen, K. Gokay and J. Wilson, unpublished work).

The sites on the endotubin molecule that comprise the substrate for proteolytic processing are now known. It seems likely that there are two cleavage sites, since removal of all $N$-linked carbohydrates results in two bands on Western blots. However, attempts to obtain the N-terminal peptide sequence of the $74 \mathrm{kDa}$ band were unsuccessful. Endotubin does contain two R-X-R motifs at positions 356-358 and 368-370. Cleavage at these sites would result in polypeptides of predicted molecularmass $39704 \mathrm{kDa}$ and $41083 \mathrm{kDa}$, which is similar to the sizes of the polypeptides present after removal of $N$-linked carbohydrates. The R-X-R motif is found at proteolytic processing sites in the intestinal proteins sucrase-isomaltase (R-T-R) [39] and the meprin A $\alpha$-subunit precursor (R-T-R) [40].

The carbohydrate composition of endotubin appears to be similar to other glycoproteins that reside on the cell surface or in the lysosomal compartment [22,23,41-43]. For example, some cell surface glycoproteins [22], lysosomal membrane proteins $[23,41,43]$ and endotubin contain high-mannose oligosaccharides and complex tri- or tetra-antennary $N$-linked carbohydrate chains [42]. However, unlike lysosomal membrane proteins in which as much as $60-70 \%$ of the molecular mass is composed of carbohydrate, the major, low-molecular-mass form of endotubin appears to be approx. $25 \%$ carbohydrate.

The function of endotubin remains unknown. The weak homology with microvillar peptidases suggest that it may have arisen from a gene duplication event. Its expression in the apical endosomes of developing intestine in several species suggests that it is critical for development of the intestinal epithelium [44]. Preliminary screens of a hepatoma cDNA library also suggest that related proteins may exist in other tissues (B. A. Speelman and J. M. Wilson, unpublished work), but the degree of similarity remains to be established. In the meantime, this protein can serve as a valuable marker of the early endosomal compartment for the study of endosomal biogenesis and dynamics.

This work was supported by National Institutes of Health grant DK-43329 and Arizona Disease Control Research Commission contract 9529 (to J.M.W.).

\section{REFERENCES}

1 Trowbridge, I. S., Collawn, J. F. and Hopkins, C. R. (1993) Annu. Rev. Cell Biol. 9 129-161

2 Geuze, H. J., Slot, J. W., Strous, G. J. A. M., Lodish, H. F. and Schwartz, A. L. (1983) Cell 32, 277-287
3 Geuze, H. J., Slot, J. W., Strous, G. J. A. M., Peppard, J., von Figura, K., Hasilik, A. and Schwartz, A. L. (1984) Cell 37, 195-204

4 Gonnella, P. A. and Neutra, M. R. (1984) J. Cell Biol. 99, 909-917

5 Griffiths, G., Hoflack, B., Simons, K., Mellman, I. and Kornfeld, S. (1988) Cell 52, 329-341

6 Schmid, S., Fuchs, R., Male, P. and Mellman, I. (1988) Cell 52, 73-83

7 Bomsel, M., Prydz, K., Parton, R. G., Gruenberg, J. and Simons, K. (1989) J. Cell Biol. 109, 3243-3258

8 Fujita, M., Reinhart, F. and Neutra, M. (1990) J. Cell Sci. 97, 385-394

9 Parton, R. G., Prydz, K., Bomsel, M., Simons, K. and Griffiths, G. (1989) J. Cell Biol. 109, 3259-3272

10 Abrahamson, D. R. and Rodewald, R. (1981) J. Cell Biol. 91, 270-280

11 Apodaca, G., Katz, L. A. and Mostov, K. E. (1994) J. Cell Biol. 125, 67-86

12 Barroso, M. and Sztul, E. (1994) J. Cell Biol. 124, 83-100

13 Gonnella, P. A., Siminoski, K., Murphy, R. A. and Neutra, M. R. (1987) J. Clin. Invest. 80, 22-32

14 Siminoski, K., Gonnella, P., Bernanke, J., Owen, L., Neutra, M. and Murphy, R. A. (1986) J. Cell Biol. 103, 1979-1990

15 Wilson, J. M., Whitney, J. A. and Neutra, M. R. (1987) J. Cell Biol. 105, 691-703

16 Speelman, B. A., Allen, K., Grounds, T. L., Neutra, M. R., Kirschhausen, T. and Wilson, J. M. (1995) J. Biol. Chem. 270, 1583-1589

17 Semenza, G. (1986) Annu. Rev. Cell Biol. 2, 255-313

18 Laemmli, U. K. (1970) Nature (London) 227, 680-685

19 Wilson, J. M. and Colton, T. L. (1997) J. Cell Biol. 136, 319-330

20 Babitt, J., Trigatti, B., Rigotti, A., Smart, E. J., Anderson, R. G. W., Xu, S. and Krieger, M. (1997) J. Biol. Chem. 13242-13249

21 Tarentino, A. L., Gomez, C. M. and Plummer, Jr., T. H. (1985) Biochem. 24 4665-4671

22 Bartles, J. R., Braiterman, L. T. and Hubbard, A. L. (1985) J. Biol. Chem. 260 12792-12802

23 Carlsson, S. R., Roth, J., Piller, F. and Fukudu, M. (1988) J. Biol. Chem. 263 18911-18919

24 Elder, J. H. and Alexander, S. (1982) Proc. Natl. Acad. Sci. U.S.A. 79, 4540-4544

25 Kitamoto, Y., Yuan, X., Wu, Q., McCourt, D. W. and Sadler, J. E. (1994) Proc. Natl. Acad. Sci. U.S.A. 91, 7588-7592

26 Wilson, J. M., Whitney, J. A. and Neutra, M. R. (1991) J. Cell Sci. 100, 133-143

27 Hauri, H.-P., Quaroni, A. and Isselbacher, K. J. (1979) Proc. Natl. Acad. Sci. U.S.A. 76, 5183-5186

28 Hauri, H.-P., Quaroni, A. and Isselbacher, K. J. (1980) Proc. Natl. Acad. Sci. U.S.A. 77, 6629-6633

29 Hauri, H.-P., Wacker, H., Rickli, E. E., Bigler-Meier, B., Quaroni, A. and Semenza, G. (1982) J. Biol. Chem. 257, 4522-4528

30 Quaroni, A. (1985) Dev. Biol. 111, 280-292

31 Hauri, H. P., Sterchi, E. E., Bienz, D., Fransen, J. A. M. and Marxer, A. (1985) J. Cell Biol. 101, 838-851

32 Buller, H. A., Montgomery, R. K., Sasak, W. V. and Grand, R. J. (1987) J. Biol. Chem. 262, 17206-17211

33 Marchand, P., Tang, J., Johnson, G. D. and Bond, J. S. (1995) J. Biol. Chem. 270 5449-5456

34 Milhiet, P. E., Chevallier, S., Corbeil, D., Seidah, N. G., Crine, P. and Boileau, G. (1995) Biochem. J. 309, 683-688

35 Wallin, R., Stanton, C. and Ross, R. P. (1994) Thromb. Res. 73, 395-405

36 Ferlinz, K., Hurwitz, R., Vielhaber, G., Suzuki, K. and Sandhoff, K. (1994) Biochem J. 301, 855-862

37 Tikkanen, R., Riikonen, A., Oinonen, C., Rouvinen, J. and Peltonen, L. (1996) EMBO J. 15, 2954-2960

38 Seemuller, E., Lupas, A. and Baumeister, W. (1996) Nature (London) 382, 468-470

39 Hunziker, W., Spiess, M., Semenza, G. and Lodish, H. F. (1986) Cell 46, 227-234

40 Jiang, W., Gorbea, C. M., Flannery, A. V., Beynon, R. J., Grant, G. A. and Bond, J. S. (1992) J. Biol. Chem. 267, 9185-9193

41 Barriocanal, J. G., Bonifacino, J. S., Yuan, L. and Sandoval, I. (1986) J. Biol. Chem. 261, 16755-16763

42 Howe, C. L., Granger, B. L., Hull, M., Green, S. A., Gabel, C. A., Helenius, A. and Mellman, I. (1988) Proc. Natl. Acad. Sci. U.S.A. 85, 7577-7581

43 Lippincott-Schwarz, J. and Fambrough, D. M. (1986) J. Cell Biol. 102, 1593-1605

44 Trahair, J. F., Wilson, J. M. and Meutra, M. R. (1995) J. Pediatr. Gastroenterol. Nutr. 21, 277-287

Received 18 August 1997/10 October 1997; accepted 23 October 1997 